\title{
Metal trace elements in mussels in Urubuqueçaba Island, Santos Bay, Brazil
}

\author{
Marcos Bührer Campolim(1), Marcelo Barbosa Henriques(2), Maria Letizia Petesse ${ }^{(2)}$, \\ Karina Fernandes Oliveira Rezende ${ }^{(2)}$ and Edison Barbieri(2)
}

(1)Instituto Florestal, Rua do Horto, no 931, CEP 02377-000 São Paulo, SP, Brazil. E-mail: marcoscampolim@yahoo.com.br
(2)Instituto de Pesca, Avenida Francisco Matarazzo, no 455, Parque da Água Branca, CEP 05001-900 São Paulo, SP, Brazil. E-mail:
henriquesmb@gmail.com, mlpetesse@gmail.com, karinaforezende@yahoo.com.br, edisonbarbieri@yahoo.com.br

Abstract - The objective of this work was to verify the existence of bioaccumulation in mussels of the species Perna perna, by determining the concentration of metal trace elements, in Urubuqueçaba Island, Santos Bay, Santos, SP, Brazil. Mussels were collected in natural banks and rocky shores, and sampling took place from April 2010 to June 2011. The concentration of the trace metal elements - aluminum, cadmium, cromium, copper, iron, manganese, nickel, lead, and zinc - was determined according to mussel sex, length, and seasonality classes, in a flame atomic absorption spectrometer. Statistical analyses were applied to the results with the use of the software PAST, with parametric and nonparametric approaches, at 5\% probability. In the summer, mussels show the highest concentrations of cadmium, copper, lead, and zinc. Females of $P$. perna concentrate more copper; for the other elements, there are no significant differences between sexes. The length classes with the highest concentrations are $3.5-5.5 \mathrm{~cm}$ for $\mathrm{Al}$ and $\mathrm{Fe}$, and $6.5-8.5 \mathrm{~cm}$ for $\mathrm{Cr}$.

Index terms: Perna perna, bivalve mollusks, bioaccumulation, seasonality.

\section{Elementos-traço metálicos em mexilhões da Ilha Urubuqueçaba, na Baía de Santos, Brasil}

\begin{abstract}
Resumo - O objetivo deste trabalho foi verificar a existência de bioacumulação em mexilhões da espécie Perna perna, por meio da determinação da concentração dos elementos-traço metálicos, na Ilha Urubuqueçaba, na Baía de Santos, Santos, SP, Brasil. Os mexilhões foram coletados em bancos naturais e costão rochoso, e as amostragens ocorreram no período de abril de 2010 a junho de 2011. A concentração dos elementos-traço metálicos - alumínio, cádmio, cromo, cobre, ferro, manganês, níquel, chumbo e zinco - foi determinada de acordo com o sexo, o comprimento e as classes de sazonalidade do mexilhão, em espectrômetro de absorção atômica de chama. Análises estatísticas foram aplicadas aos resultados com o uso do programa PAST, com abordagens paramétricas e não paramétricas, a $5 \%$ de probabilidade. No verão, os mexilhões apresentam as maiores concentrações de cádmio, cobre, chumbo e zinco. As fêmeas de P. perna concentram mais cobre; quanto aos demais elementos, não há diferenças significativas entre os sexos. As classes de comprimento que apresentam maiores concentrações são a de 3,5-5,5 cm para $\mathrm{Al}$ e Fe, e a de 6,5-8,5 cm para $\mathrm{Cr}$.
\end{abstract}

Termos para indexação: Perna perna, moluscos bivalves, bioacumulação, sazonalidade.

\section{Introduction}

Some metal trace elements, such as zinc, iron, copper, and manganese, at low concentrations, are essential for the metabolism of plants and animals, for their participation in respiratory pigments, metalloprotein formation, and activation of enzymatic complexes, among other functions. At high concentrations, they are toxic and harmful, especially cadmium, chromium, mercury, and lead, which interfere with the action of enzymes and other biochemical agents on aquatic organisms (Ferreira et al., 2013; Marengoni et al., 2013).
For humans, trace elements have been considered relevant contaminants because of their radioactivity, toxicity and, in some cases, carcinogenicity and mutagenicity (Carmo et al., 2011). The main route of intoxication by inorganic pollutants, associated with aquatic systems, is the consumption of contaminated fish (Barbieri et al., 2010; Santos et al., 2014).

Due to the large volume of water in the oceans, any contaminant tends to be diluted and, as a result, damages can be reduced. However, there is no doubt that metal trace elements, can cause risk, as they are not biodegradable, mainly because they are easily 
incorporated into the food chain (Barbieri et al., 2010).

Bivalve mollusks, such as mussels, are known for their ability to concentrate trace elements (Resgalla Jr. et al., 2008; Wallner-Kersanach \& Bianchini, 2008); these animals can accumulate cadmium concentrations up to 100 thousand times higher than the ones observed in the waters where they live (Galvão et al., 2009). The retention and absorption of lead in the digestive tract of mollusks are linked to several factors that should be considered, such as salinity, hygroscopicity, concentration, larval phase, respiratory rate, and duration of exposure (Barbieri, 2009a, 2009b; Barros \& Barbieri, 2012). The effect of lead on mussels decreases food absorption, negatively affecting the energy flow of the animal metabolism (Wang et al., 2013).

The mussel Perna perna Linnaeus, 1758, is able to respond to the variation of pollutants in the environment, and it is recognized as an efficient bioindicator in marine aquatic environments, besides having a known biology and being a sessile animal of wide geographical distribution (Ferreira et al., 2013; Marengoni et al., 2013). This species seems to respond reliably to the presence of metal elements usually derived from domestic sewage disposal (Francioni et al., 2004). The use of the P. perna mussel as a biomonitor requires the understanding of its biology and the functioning of the environment, as well as the intensity and distribution of the source of availability (Francioni et al., 2004; Maanan, 2008).

Santos Bay comprises the estuarine system of Santos and São Vicente municipalities. The region is home to the largest port in Latin America (Porto de Santos) and an industrial pole with steel, petrochemical and fertilizer industries, which is the main source of chemical pollutants for the rivers, estuary system, bay, and adjacent marine environments, both for the diversity and quantity of substances currently emitted, and for the past contamination that constitutes an environmental liability (Casarini et al., 2010).

In Santos Bay, P. perna is the most abundant bivalve (Henriques \& Casarini, 2009) and, even with the presence of contaminants, its extraction from natural banks for consumption and commercialization occurs (Casarini et al., 2010). There is a lack of scientific data related to the content of metal trace elements in mussels in tropical regions, specifically in Brazil (Ferreira et al., 2013), regarding the effect of seasonal and physiological variations related to bioaccumulation.
The objective of this work was to verify the existence of bioaccumulation by determining the concentration of metal trace in mussels of the species Perna perna, in Urubuqueçaba Island, Santos Bay, in the state of São Paulo, Brazil.

\section{Materials and Methods}

Perna perna mussels were collected in the sea, from April 2010 to June 2011, in natural banks and rocky shores, up to $1 \mathrm{~m}$ depth (mesotidal), always at a low tide, in the Urubuqueçaba Island ( $23^{\circ} 58^{\prime} 26^{\prime}$ 'S, $\left.46^{\circ} 21^{\prime} 08^{\prime \prime} \mathrm{W}\right)$, located in Santos Bay, in the coast of São Paulo state, Brazil (Figure 1).

Samples of $P$. perna mussels consisted of adult animals $(>3.5 \mathrm{~cm})$. Eight collections were carried out, two per season of the year. Collected organisms were cleaned from the fouling material with appropriate knife, and stored in plastic bags moistened with local water, which were sealed, identified, placed in styrofoam ice packs, taken to the laboratory, and frozen.

In order to determine the concentration of the metal trace elements $\mathrm{Al}, \mathrm{Cd}, \mathrm{Cr}, \mathrm{Cu}, \mathrm{Fe}, \mathrm{Mn}, \mathrm{Ni}, \mathrm{Pb}$, and $\mathrm{Zn}, 30$ samples were selected from each of the eight samples, composed of 50\% males and 50\% females. For each sex, there was separation into three length classes: $3.5-5.5,5.5-6.5$, and $6.5-8.5 \mathrm{~cm}$, totaling 240 mussel samples. Subsequently, the samples were thawed at room temperature $\left(24 \pm 2^{\circ} \mathrm{C}\right)$, then they were opened and peeled. The soft tissue was dried in an air-circulation oven at $60^{\circ} \mathrm{C}$, until constant mass was achieved. The process of opening with microwaves followed a procedure used by Barros $\&$ Barbieri (2012), which consisted on the addition of 10 $\mathrm{mL}$ of pure supra $\mathrm{HNO}_{3}$ to $0.5 \mathrm{~g}$ of mussel tissue, with subsequent heating at $60^{\circ} \mathrm{C}$ for two hours, for destruction of resistant fats. The opening solutions were transferred to a $50 \mathrm{~mL}$ volumetric flask, and completed to final volume with ultrapure water.

The determination of trace elements concentration was performed using the AA-6800 flame atomic absorption spectrometer (Shimadzu, Kyoto, Japan) as a source of atomization. The mean concentration of each trace element was calculated for five mussel samples ( $\mu \mathrm{g} \mathrm{g}^{-1}$ dry mass). In the digestion process, three control solutions were prepared similarly to those of the samples, for the quality control of the analysis. The standard reference material used was the 15 SRM certified oyster tissue 
(oyster tissue, No. 1566b, NIST, USA) (Barros \& Barbieri, 2012) was used.

The statistical software PAST, version 2.17 (Hammer et al., 2001), was used to perform descriptive statistics, normal probability graphs, and analysis results (boxplot model, where the centerline is the median), at $5 \%$ probability.

To answer the hypothesis that there were no significant differences in trace elements concentrations between males and females, the Student's t-test was used as the parametric statistic, and the Mann-Whitney test (Zar, 2010) was used as the nonparametric test.

For seasonality and length classes, the one-way analysis of variance was used, followed by the Tukey's multiple comparison test, at $5 \%$ probability.

To verify the normality and homogeneity of the variances, the Shapiro-Wilk and Levene tests, were used, respectively. When data did not meet the homogeneity of the variances and normality of the residues, a KruskalWallis nonparametric analysis was used, followed by the Bonferroni multiple comparison test.

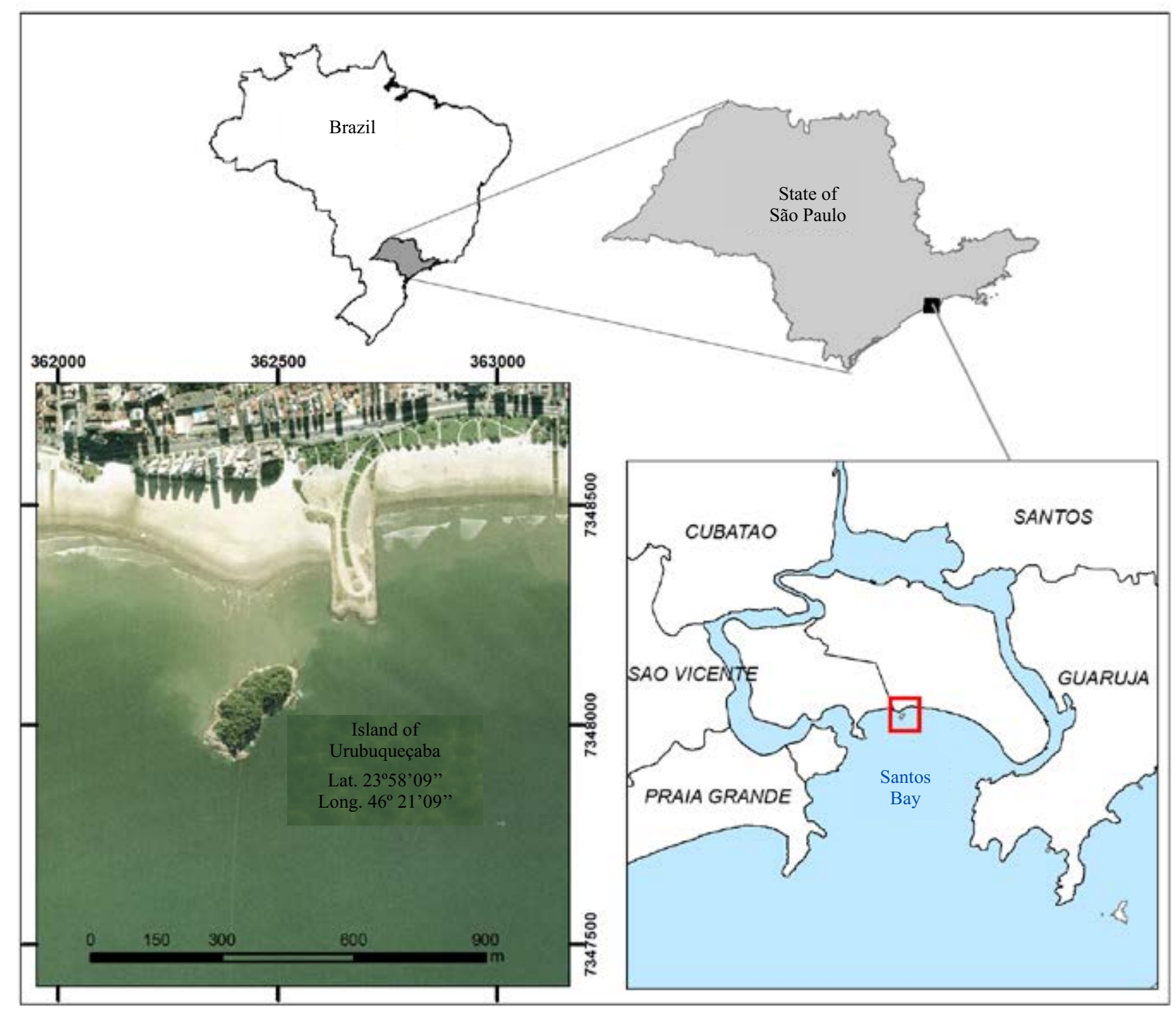

Figure 1. Location of Urubuqueçaba Island, Santos Bay, São Paulo state, Brazil. Perna perna mussels were collected from marine water, rocky shores, and midlittoral region. 


\section{Results and discussion}

Santos Bay is relatively sheltered and receives contributions from Santos and São Vicente channels, constituting a zone of mixture of sea water and brackish waters coming from the estuaries. The study area is located in salt water, according to a resolution of the Conselho Nacional do Meio Ambiente (Conama, 2005). The main sources of direct pollution in this area are sewage systems, launched by the Santos submarine emissary and by the urban drainage channels, and dredged sediments of the port channel which were previously improperly dumped into the bay (Casarini et al., 2010). According to 40-year-data from the Instituto Nacional de Meteorologia, for the region of study, the highest accumulated monthly rainfall occurs in the summer (Pellegatti \& Galvani, 2010).

As to the seasonal variations, the mollusks had higher concentrations of $\mathrm{Cd}$ and $\mathrm{Pb}$ in the summer (Figure 2), and of $\mathrm{Cu}$ and $\mathrm{Zn}$ in the summer and autumn, with the medians and maximum values in the summer. Despite
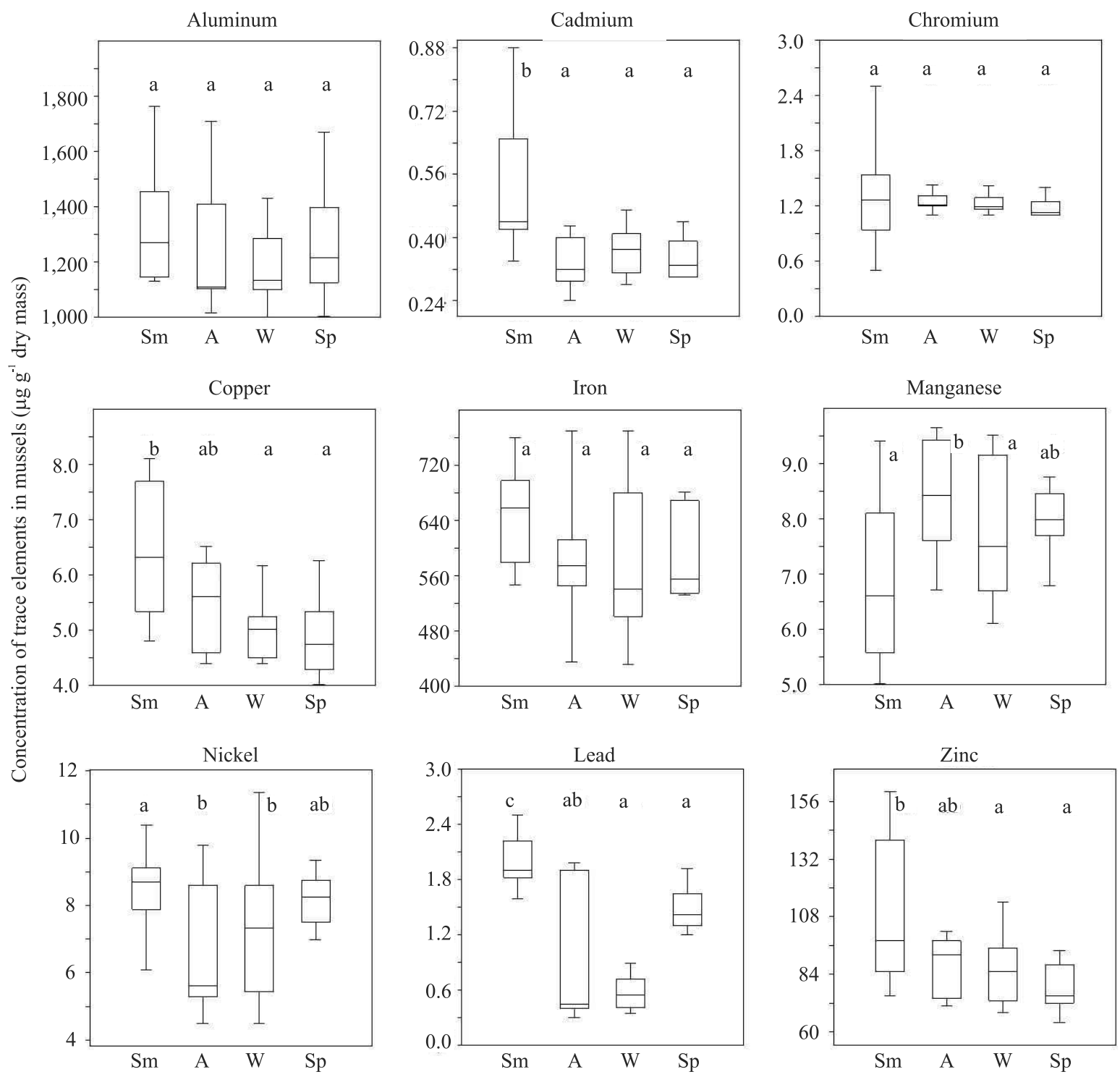

Figure 2. Concentration of trace elements in mussels, and seasonality as a function. Sm (summer), A (autumn), W (winter), and Sp (spring). Equal letters on the standard deviation bars do not represent significant differences by the analyses of variance, at $5 \%$ probability. Box-plot: line, median; box, $25^{\text {th }}$ and $75^{\text {th }}$ percentiles; whiskers, minimum and maximum. 
the records of higher concentrations in the winter, $\mathrm{Ni}$ showed larger medians in the summer and in the spring; and $\mathrm{Mn}$ had its highest concentrations in the autumn, however, with no difference in comparison to spring.

$\mathrm{Al}, \mathrm{Cr}$ and $\mathrm{Fe}$ elements did not show differences between seasons; however $\mathrm{Al}$ and $\mathrm{Cr}$ showed the highest median and maximum concentrations in the summer, whereas Fe had median values for the same season.

The concentrations of trace elements in mussels are controlled mainly by local environmental levels, and are related to the hydrological parameters of the environment (Maanan, 2008).

For most of the trace elements analyzed, the highest concentrations occurred in the summer, which is the period with the highest rainfall in the evaluated area (Pellegatti \& Galvani, 2010), which may have led to the greater number of trace elements of natural or anthropogenic origin by rainfall and fluvial drainages to the coastal region and, consequently, greater bioavailability for mussels.

Specifically for $\mathrm{Zn}$, the highest concentration in the summer could be related not only to the higher rainfall of this period, but also to reproduction (Casarini et al., 2010), since reproductive peaks were identified in January (Galvão et al., 2009). For the Mytilus edulis mussel, higher concentrations of $\mathrm{Zn}$ were observed in the spawning stage, which is attributed to the synthesis of a group of proteins, such as metallothioneins that are responsible for the preferential accumulation of some metals (Carvalho et al., 2001).

Aquatic organisms tend to accumulate metal trace elements in their tissue, which leads to great risks of contamination within the trophic chain, even when the levels of these compounds in the water are below the maximum concentration recommended by the legislation (Niencheski et al., 2014). Interferences of seasonality on the bioaccumulation of trace metals in $P$. perna mussels may have different profiles depending on the study region and survey period. Ferreira et al. (2004), when evaluating P. perna mussels in three beaches in the northern coast of Rio de Janeiro, did not find a seasonal trend of accumulation.

For the northern coast of São Paulo state, the highest concentrations of $\mathrm{Cd}, \mathrm{Cr}$, and $\mathrm{Pb}$ were found in the winter in $P$. perna mussels, in Ubatuba Bay (Avelar et al., 2000). In Cocanha beach, concentrations of $\mathrm{Cd}$ were recorded in the spring, and of $\mathrm{Fe}$ in the summer (Catharino et al., 2008), besides $\mathrm{Cd}, \mathrm{Cr}, \mathrm{Fe}$, and $\mathrm{Pb}$ in the spring, and $\mathrm{Zn}$ in the winter (Catharino et al., 2012).
The results obtained for that region differ from those obtained in the present study.

In Santos Bay, Catharino et al. (2012) identified for the location of Itaipu, in P. perna, higher concentrations of $\mathrm{Cd}, \mathrm{Pb}$, and $\mathrm{Zn}$ in the summer, Fe in the winter, and $\mathrm{Cr}$ in the autumn. For the Island of Palmas, $\mathrm{Cd}, \mathrm{Fe}$, and $\mathrm{Zn}$ showed the highest concentrations in the winter, and $\mathrm{Pb}$ in the summer. Thus, there were differences between nearby localities, but when comparing them to the present work, which was carried out in the same region, similar tendencies are noted for the same trace metals.

The present study corroborates the foundings by Maanan (2008), in Mytilus galloprovincialis mussels, in the coastal region of Morocco, for $\mathrm{Cd}, \mathrm{Cr}, \mathrm{Ni}, \mathrm{Pb}$, and $\mathrm{Zn}$ with the highest concentrations in the spring and the summer, for $\mathrm{Mn}$ in the spring and winter, and for $\mathrm{Cu}$, in the autumn and spring.

Rainbow et al. (2004) evaluated Mytillus trossulus in the Gulf of Gdansk, Baltic Sea, and identified the highest concentrations of $\mathrm{Ni}$ in the winter, $\mathrm{Fe}$ in the winter and spring, $\mathrm{Zn}$ and $\mathrm{Mn}$ in the spring, and $\mathrm{Pb}$ in the summer and spring; the values for $\mathrm{Mn}$ and $\mathrm{Pb}$ are corroborated by those of the present study. M. galloprovinciallis, in the Adriatic Sea, Italy, showed the lowest concentrations in the summer and the highest in the winter for $\mathrm{Cu}, \mathrm{Fe}$ and $\mathrm{Mn}$, and in the autumn for $\mathrm{Cd}, \mathrm{Pb}$, and $\mathrm{Zn}$. Only $\mathrm{Zn}$ showed similarity to the results obtained in the present work (Vernocchi et al., 2007). Higher concentrations in colder months were also identified by Mubiana et al. (2005) for M. edulis in the Netherlands, with $\mathrm{Cd}, \mathrm{Cr}$, $\mathrm{Zn}$ in the winter, and $\mathrm{Fe}, \mathrm{Mn}, \mathrm{Ni}$, and $\mathrm{Pb}$ in the spring; the values for $\mathrm{Mn}$ and $\mathrm{Ni}$ are corroborated by those observed in the present work.

Seasonal variations may cause changes in the body mass of aquatic organisms, and oscillations in the concentration of metal trace elements in the soft tissues of marine mussels, resulting in an unpredictable estimation of the bioavailability of metals (Degger et al., 2016). Another factor that causes variations in the concentration of trace elements is the type of tissue analyzed. Geffard et al. (2005) identified the highest concentrations of $\mathrm{Cd}$ for gills in the autumn, and for the digestive glands in the summer, when evaluating concentrations of $\mathrm{Cd}, \mathrm{Cu}$, and $\mathrm{Zn}$ in tissues of M. edulis mussels in the coast of France. Kumar et al. (2015) have identified a greater stability 
in the concentration of trace elements in the mussel shell than in soft tissues. In the present study, evaluations were performed only for the presence of metal trace elements in soft tissue, and differences were found in comparison to the above mentioned works.

It is noteworthy that, for studies carried out in the Southeastern Brazil, as in other countries, the results do not follow a pattern of seasonal concentration of trace elements in mussels.

There was no difference in the concentrations between sexes for $\mathrm{Al}, \mathrm{Cd}, \mathrm{Cr}, \mathrm{Fe}, \mathrm{Mn}, \mathrm{Ni}, \mathrm{Pb}$, and $\mathrm{Zn}$. Females of $P$. perna showed significantly higher $\mathrm{Cu}$ levels than males (Figure 3). Similar results for $\mathrm{Cu}$ accumulation were observed for the coast of the Rio de Janeiro state, by Carvalho et al. (2001) and Francioni et al. (2004).
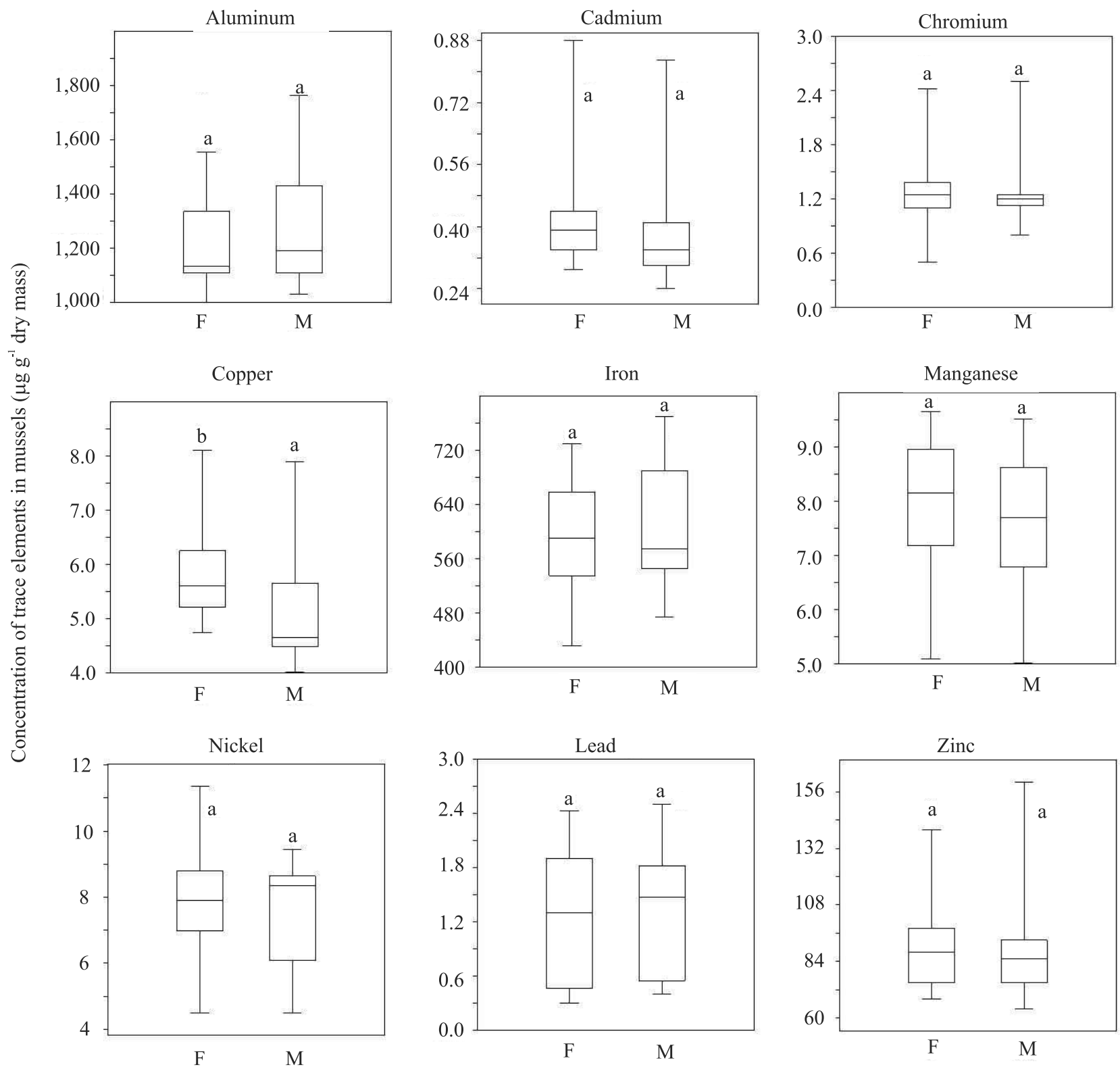

Figure 3. Concentration of trace elements in mussels, according to sex: $F$, females; and $M$, males. Equal letters on the standard deviation bars do not represent significant differences by the analyses of variance, at $5 \%$ probability. Box-plot: line, median; box, $25^{\text {th }}$ and $75^{\text {th }}$ percentiles; whiskers: minimum and maximum. 
This difference may be related to the different stages of the reproductive cycle, as observed by Carvalho et al. (2001) for M. edulis, in which the highest concentrations of $\mathrm{Cu}$ occurred during the stage of sexual maturity, this is attributed to the synthesis of a group of proteins, among which there were metallothioneins induced by hormonal stimuli.

The present study corroborates the results in P. perna obtained for $\mathrm{Al}, \mathrm{Cd}$, and $\mathrm{Ni}$ (Carvalho et al., 2001), and for $\mathrm{Cr}$, $\mathrm{Fe}, \mathrm{Mn}, \mathrm{Pb}$, and $\mathrm{Zn}$ (Carvalho et al., 2001; Ferreira et al., 2004). The present work also corroborates the high concentrations of Cd and Ni (Ferreira et al., 2004), and $\mathrm{Zn}$ (Francioni et al., 2004), observed in female mussels of P. perna.

As to the mussel length classes (Figure 4), significant maximum and median concentrations occurred for $\mathrm{Al}$ and $\mathrm{Fe}$ in the $3.5-5.5 \mathrm{~cm}$ class (class with lower variability than the others), and $\mathrm{Cr}$ in the $6.5-8.5 \mathrm{~cm}$
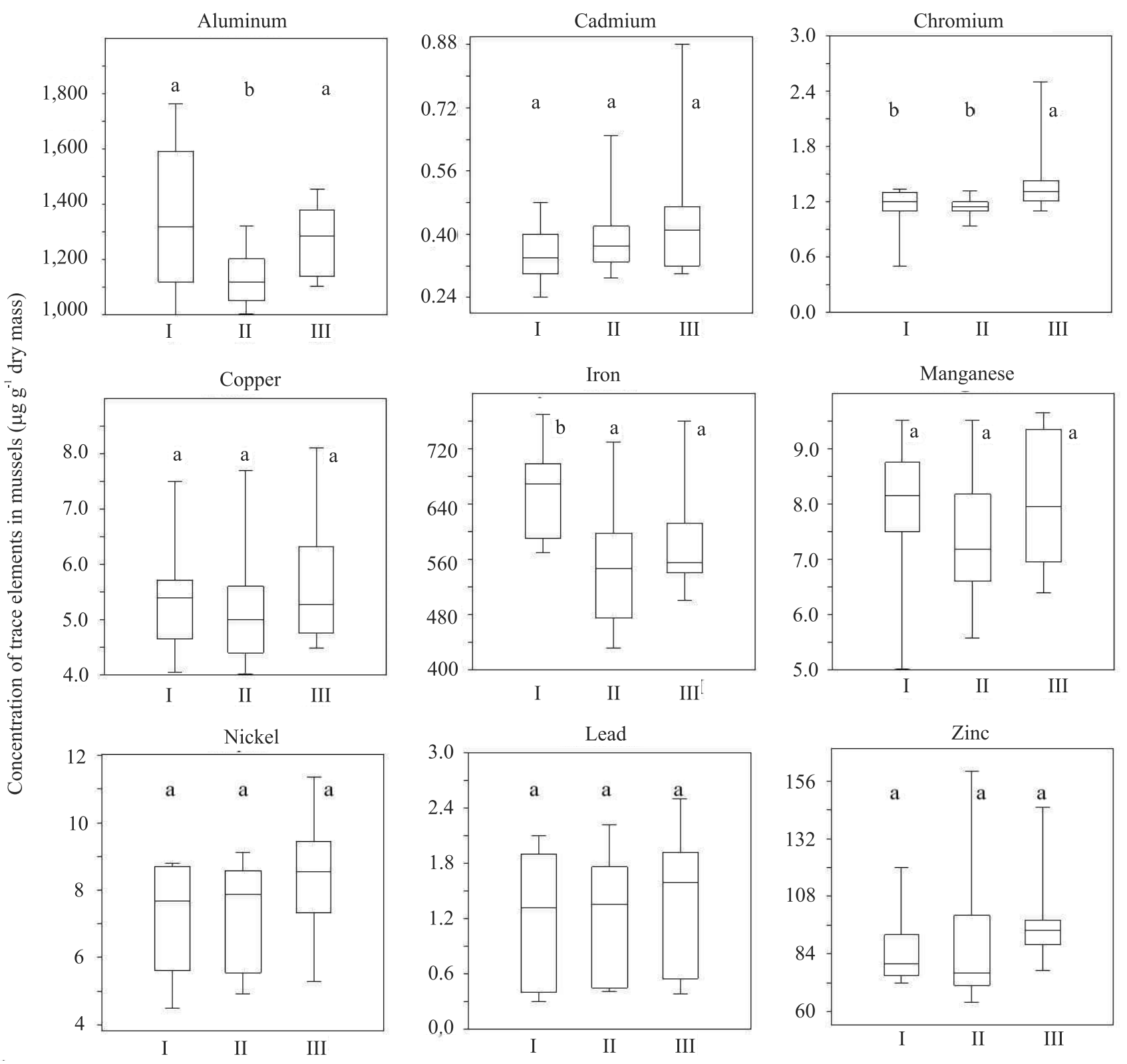

Figure 4. Concentration of trace elements in mussels as a length function. Classes of length: I, $3.5-5.5 \mathrm{~cm}$; II, $5.5-6.5 \mathrm{~cm}$; and III, $6.5-8.5 \mathrm{~cm}$. Equal letters on the standard deviation bars do not represent significant differences by the analyses of variance test, at $5 \%$ probability. Box-plot: line, median; box, $25^{\text {th }}$ and $75^{\text {th }}$ percentiles; whiskers: minimum and maximum. 
class. For the other elements, there were no significant differences. However, the maximum concentrations of $\mathrm{Cd}, \mathrm{Cu}, \mathrm{Ni}$, and $\mathrm{Pb}$, and the highest medians of $\mathrm{Mn}$, and $\mathrm{Zn}$ occurred in the class of $6.5-8.5 \mathrm{~cm}$ of the mussels.

There was little variation between the length classes, which is equivalent to the results obtained by Carvalho et al. (2001), who evaluated the same species and length classes, and identified the highest concentrations for $\mathrm{Cd}$, $\mathrm{Cr}, \mathrm{Cu}, \mathrm{Ni}, \mathrm{Pb}$, and $\mathrm{Zn}$ in the $6.5-8.5 \mathrm{~cm}$ class, and for $\mathrm{Al}, \mathrm{Fe}$, and $\mathrm{Mn}$ in the $3.5-5.5 \mathrm{~cm}$ class. These results are corroborated by those obtained in the present work for $\mathrm{Al}, \mathrm{Fe}$, and $\mathrm{Cr}$. The greatest concentrations of trace elements were observed in mussels in the $6.8-8.5 \mathrm{~cm}$ and $3.5-5.5 \mathrm{~cm}$ classes, which may be related to the fact that organisms vary their concentrations of metal trace elements according to the phase of their life cycle (Catharino et al., 2012), and that larger individuals would have been exposed to the environment for longer.

\section{Conclusions}

1. The metal trace elements $\mathrm{Al}, \mathrm{Cd}, \mathrm{Cr}, \mathrm{Cu}, \mathrm{Fe}, \mathrm{Mn}$, $\mathrm{Ni}, \mathrm{Pb}$, and $\mathrm{Zn}$ are concentrated in the Perna perna mussel, and differences are mainly related to seasonality, followed by length classes; and are less significant in relation to sex, for the conditions of Urubuqueçaba Island, in Santos Bay, Santos, SP, Brazil.

2. In the summer, mussels show the highest concentrations for $\mathrm{Cd}, \mathrm{Cu}, \mathrm{Pb}$, and $\mathrm{Zn}$.

3. Females of $P$. perna concentrate more $\mathrm{Cu}$ and, for the other elements, there are no significant differences between sexes.

4. The length classes with the highest metal trace concentrations are $3.5-5.5 \mathrm{~cm}$ for $\mathrm{Al}$ and $\mathrm{Fe}$, and $6.5-$ $8.5 \mathrm{~cm}$ for $\mathrm{Cr}$.

\section{Acknowledgments}

To Fundação de Amparo à Pesquisa do Estado de São Paulo (Fapesp, process No. 2016/23842-5), for financial support.

\section{References}

AVELAR, W.E.P.; MANTELATTO, F.L.M.; TOMAZELLI, A.C.; SILVA, D.M.L.; SHUHAMA, T.; LOPES, J.L.C. The marine mussel Perna perna (mollusca, bivalvia, mytilidae) as an indicator of contamination by heavy metals in the Ubatuba Bay,
São Paulo, Brazil. Water, Air and Soil Pollution, v.118, p.65-72, 2000. DOI: 10.1023/A:1005109801683.

BARBIERI, E. Concentration of heavy metals in tissues of green turtles (Chelonia mydas) sampled in the Cananéia estuary, Brazil. Brazilian Journal of Oceanography, v.57, p.243-248, 2009a. DOI: $10.1590 /$ S1679-87592009000300007.

BARBIERI, E. Effects of zinc and cadmium on oxygen consumption and ammonium excretion in pink shrimp (Farfantepenaeus paulensis, Pérez-Farfante, 1967, Crustacea). Ecotoxicology, v.18, p.312-318, 2009b. DOI: 10.1007/s10646-008-0285-y.

BARBIERI, E.; PASSOS, E. de A.; ARAGÃO, K.A.S.; SANTOS, D.B.; GARCIA, C.A.B. Assessment of trace metal levels in catfish (Cathorops spixii) from Sal River Estuary, Aracaju, state of Sergipe, Northeastern Brazil. Water Environment Research, v.82, p.2301-2305, 2010. DOI: 10.2175/106143009X12465435982935.

BARROS, D.; BARBIERI, E. Análise da ocorrência de metais: Ni, $\mathrm{Zn}, \mathrm{Cu}, \mathrm{Pb}$ e $\mathrm{Cd}$ em ostras (Crassostrea brasiliana) e sedimentos coletados no Estuário de Cananeia, SP (Brasil). O Mundo da Saúde, v.36, p.635-642, 2012.

CARMO, C.A. do; ABESSA, D.M. de S.; MACHADO-NETO, J.G.M. Metais em águas, sedimentos e peixes coletados no estuário de São Vicente-SP, Brasil. O Mundo da Saúde, v.35, p.64-70, 2011.

CARVALHO, C.E.V.; CAVALCANTE, M.P.O.; GOMES, M.P.; FARIA, V.V.; REZENDE, C.E. Distribuição de metais pesados em mexilhões (Perna perna, L.) da Ilha de Santana, Macaé, SE, Brasil. Ecotoxicology and Environmental Restoration, v.4, p.15, 2001.

CASARINI, L.M.; HENRIQUES, M.B.; GRAÇA-LOPES, R.; SOUZA, M.R. de. Chemical and bacteriological evaluation of the water and mussels from Santos bay, São Paulo, Brazil. Revista do Instituto Adolfo Lutz, v.69, p.297-303, 2010.

CATHARINO, M.G.M.; VASCONCELLOS, M.B.A.; KIRSCHBAUM, A.A.; GASPARRO, M.R.; MINEI, C.C.; SOUSA, E.C.P.M. de; SEO, D.; MOREIRA, E.G. Biomonitoring of coastal regions of São Paulo state, Brazil, using mussels Perna perna. Journal of Radioanaytical and Nuclear Chemistry, v.291, p.113-117, 2012. DOI: 10.1007/s10967-011-1291-8.

CATHARINO, M.G.M.; VASCONCELOS, M.B.A.; SOUSA, E.C.P.M.; MOREIRA, E.G.; PEREIRA, C.D.S. Biomonitoring of $\mathrm{Hg}, \mathrm{Cd}, \mathrm{Pb}$ and other elements in coastal regions of São Paulo state, Brazil, using the transplanted mussel Perna perna (Linnaeus, 1758). Journal of Radioanaytical and Nuclear Chemistry, v.278, p.547-551, 2008. DOI: 10.1007/s10967-008-1003-1.

CONAMA. Conselho Nacional de Meio Ambiente. Resolução $\mathrm{n}^{\circ}$ 357, de 17 de março de 2005. Dispõe sobre a classificação dos corpos de água e diretrizes ambientais para o seu enquadramento, bem como estabelece as condições e padrões de lançamento de efluentes, e dá outras providências. Diário Oficial da União, de 18 mar. 2005. Seção 1, p.58-63.

DEGGER, N.; CHIU, J.M.Y.; PO, B.H.K.; TSE, A.C.K.; ZHENG, G.J.; ZHAO, D.-M.; XU, D.; CHENG, Y.-S.; WANG, X.-H.; LIU, W.H.; LAU, T.C.; WU, R.S.S. Heavy metal contamination along the China coastline: a comprehensive study using artificial mussels 
and native mussels. Journal of Environmental Management, v.180, p.238-246, 2016. DOI: 10.1016/j.jenvman.2016.05.008.

FERREIRA, A.G.; MACHADO, A.L. dos S.; ZALMON, I.R. Temporal and spatial variation on heavy metal concentrations in the bivalve Perna perna (Linnaeus,1758) on the northern coast of Rio de Janeiro State, Brazil. Brazilian Archives of Biology and Technology, v.47, p.319-327, 2004. DOI: 10.1590/S151689132004000200020 .

FERREIRA, M. da S.; MÁRCICO, E.T.; CONTE JUNIOR, C.A.; MARQUES JÚNIOR, A.N.; MANO, S.B.; SÃO CLEMENTE, S.C. de. Contaminação por metais traço em mexilhões Perna perna da costa brasileira. Ciência Rural, v.43, p.1012-1020, 2013. DOI: $10.1590 / \mathrm{S} 0103-84782013005000062$.

FRANCIONI, E.; WAGENER, A. de L.R.; CALIXTO, R. de C.; BASTOS, G.C. Evaluation of Perna perna (Linné, 1758) as a tool to monitoring trace metals contamination in estuarine and coastal waters of Rio de Janeiro, Brazil. Journal of the Brazilian Chemical Society, v.15, p.103-110, 2004. DOI: 10.1590/S010350532004000100016.

GALVÃO, P.M.A.; REBELO, M.F.; GUIMARÃES, J.R.D.; TORRES, J.P.M.; MALM, O. Bioacumulação de metais em moluscos bivalves: aspectos evolutivos e ecológicos a serem considerados para a biomonitoração de ambientes marinhos. Brazilian Journal of Aquatic Science and Technology, v.13, p.59-66, 2009. DOI: 10.14210/bjast.v13n2.p59-66.

GEFFARD, A.; AMIARD-TRIQUET, C.; AMIARD, J.-C. Do seasonal changes affect metallothionein induction by metals in mussels, Mytilus edulis? Ecotoxicology and Environmental Safety, v.61, p.209-220, 2005. DOI: 10.1016/j.ecoenv.2005.01.004.

HAMMER, Ø.; HARPER, D.A.T.; RYAN, P.D. PAST: Paleontological statistics software package for education and data analysis. Palaeontologia Electronica, v.4, p.1-9, 2001.

HENRIQUES, M.B.; CASARINI, L.M. Avaliação do crescimento do mexilhão Perna perna e da espécie invasora Isognomon bicolor em banco natural da ilha das Palmas, Baía de Santos, estado de São Paulo, Brasil. Boletim do Instituto de Pesca, v.35, p.577-586, 2009.

KUMAR, V.; SINHA, A.K.; RODRIGUES, P.P.; MUBIANA, V.K.; BLUST, R.; BOECK, G. Linking environmental heavy metal concentrations and salinity gradients with metal accumulation and their effects: a case study in 3 mussel species of Vitória estuary and Espírito Santo bay, Southeast Brazil. Science of the Total Environment, v.523, p.1-15, 2015. DOI: 10.1016/j. scitotenv.2015.03.139.

MAANAN, M. Heavy metal concentrations in marine molluscs from the Moroccan coastal region. Environmental Pollution, v.153, p.176-183, 2008. DOI: 10.1016/j.envpol.2007.07.024.
MARENGONI, N.G.; KLOSOWSKI, E.S.; OLIVEIRA, K.P. de; CHAMBO, A.P.S.; GONÇALVES JUNIOR, A.C. Bioacumulação de metais pesados e nutrientes no mexilhão dourado do reservatório da usina hidrelétrica de Itaipu Binacional. Química Nova, v.36, p.359-363, 2013. DOI: 10.1590/S0100-40422013000300002.

MUBIANA, V.K.; QADAH, D.; MEYS, J.; BLUST, R. Temporal and spatial trends in heavy metal concentrations in the marine mussel Mytilus edulis from the Western Scheldt estuary (The Netherlands). Hydrobiologia, v.540, p.169-180, 2005. DOI: 10.1007/s10750-004-7134-7.

NIENCHESKI, L.F.; MACHADO, E. da C.; SILVEIRA, I.M.O.; FLORES MONTES, M. de J. Metais traço em peixes e filtradores em quatro estuários da costa brasileira. Tropical Oceanography, v.42, p.94-93, 2014. DOI: 10.5914/1679-3013.2014.0106.

PELLEGATTI, C.H.G.; GALVANI, E. Avaliação da precipitação na Serra do Mar - SP em eventos de diferentes intensidade e duração. GeoUSP: espaço e tempo, v.27, p.147-158, 2010. Available at: <http://citrus.uspnet.usp.br/geousp/ojs-2.2.4/index. php/geousp/article/view/11>. Accessed on: Jan. 202017.

RAINBOW, P.S. Geographical and seasonal variation of trace metal bioavailabilities in the Gulf of Gdansk, Baltic Sea using mussels (Mytilus trossulus) and barnacles (Balanus improvisus) as biomonitors. Marine Biology, v.144, p.271-286, 2004. DOI: 10.1007/s00227-003-1197-2.

RESGALLA JR., C.; WEBER, L.I.; CONCEIÇÃO, M.B. da. (Ed.). O mexilhão Perna perna (L.): biologia, ecologia e aplicações. Rio de Janeiro: Interciência, 2008. 324p.

SANTOS, D.B.; BARBIERI, E.; BONDIOLI, A.C.V.; MELO, C.B. de. Effects of lead in white shrimp (Litopenaeus schmitti) metabolism regarding salinity. O Mundo da Saúde, v.38, p.16-23, 2014. DOI: 10.15343/0104-7809.20143801016023.

VERNOCCHI, P.; MAFFEI, M.; LANCIOTTI, R.; SUZZI, G.; GARDINI, F. Characterization of Mediterranean mussels (Mytilus galloprovincialis) harvested in Adriatic Sea (Italy). Food Control, v.18, p.1575-1583, 2007.

WALLNER-KERSANACH, M.; BIANCHINI, A. Metais traço em organismos: monitoramento químico e de efeitos biológicos. In: BAPTISTA NETO, J.A.; WALLNER-KERSANACH, M.; PATCHINEELAM, S.M. (Org.). Poluição marinha. Rio de Janeiro: Interciência, 2008. p.237-283.

WANG, S.-L.; XU, X.-R.; SUN, Y.-X.; LIU, J.-L.; LI, H.-B. Heavy metal pollution in coastal areas of South China: a review. Marine Pollution Bulletin, v.76, p.7-15, 2013. DOI: 10.1016/j. marpolbul.2013.08.025.

ZAR, J.H. Biostatistical analysis. $5^{\text {th }}$ ed. New Jersey: Prentice Hall, 2010. 944p.

Received on January 20, 2017 and accepted on May 5, 2017 